\title{
Prescription and administration errors of antimicrobials in a pediatric inpatient unit
}

\author{
Gabriela Miranda MEIRA ${ }^{1}$ (D) Tuany Santos SOUZA² (D), Lucas Brasileiro LEMOS² (D), Gisele da Silveira LEMOS ${ }^{1}$ (D) \\ ${ }^{1}$ Departamento de Ciências e Tecnologias. Universidade Estadual do Sudoeste da Bahia. ${ }^{2}$ Departamento de Saúde. Universidade Estadual do \\ Sudoeste da Bahia. \\ Corresponding author: Lemos GS, giselesilveiralemos@gmail.com
}

Submmitted: 15-06-2020 Resubmitted: 16-09-2020 Accepted: 01-10-2020

Peer review: Danilo Donizetti Trevisan and Aline Carrilho Menezes

\begin{abstract}
Objective: To identify errors in the prescription and administration of antimicrobials in a pediatric inpatient unit of a public teaching hospital. Methods: This is a cross-sectional study with a quantitative approach in which a direct observation was performed of the preparation and administration of antimicrobials by daytime nursing technicians/assistants in patients hospitalized in the pediatric sector, as well as of their respective prescription with the prescribed antimicrobial item, in this order for ethical issues. The assessment was carried out with the help of two checklist forms, one of which was validated, following the safety protocol for the prescription, use and administration of medications by the Brazilian Ministry of Health. The data were tabulated in the Epidata 3.1 software and analyzed in SPSS 21.0, resulting in a sample of 174 administrations and prescriptions. Results: The most frequent inpatient diagnoses for using antimicrobials were diseases of the respiratory system (52.9\%) followed by diseases of the urinary system (5.7\%). The main types of prescription errors were absence of information about the diluent (97.1\%), infusion rate (99.4\%), incorrect dose (5.8\%), and forbidden abbreviations (1.1\%). In the administrations, the types of errors observed were the following: lack of patient identification by the professional (94.3\%), lack of patient identification on the bed (12.1\%), administration time (6.3\%), and incorrect preparation and administration of the medication (1.1\%). Conclusion: The main factors that led to errors in prescription and administration were evaluated, making it necessary to implement improvements in the electronic medical record with standardization for the dilution of the antimicrobials, issuing alerts in the prescription, integration of a clinical pharmacist in the team, effective communication, and coaching and permanent training.
\end{abstract}

Keywords: medication errors, patient safety, pediatrics, drug prescriptions, anti-infective agents.

\section{Erros de prescrição e de administração de antimicrobianos em unidade de internação pediátrica}

\begin{abstract}
Resumo
Objetivo: identificar erros prescrição e administração de antimicrobianos em uma unidade de internação pediátrica de um hospital público de ensino. Métodos: Trata-se de um estudo transversal com abordagem quantitativa onde foi realizada observação direta do preparo e administração de antimicrobianos por técnicos/auxiliares de enfermagem do serviço diurno em pacientes internados no setor pediátrico e sua respectiva prescrição com item de antimicrobiano prescrito, nesta ordem por questões éticas. A avaliação foi realizada com auxílio de dois formulários, tipo checklist, sendo um deles validado, seguindo o protocolo de segurança na prescrição, uso e administração de medicamentos do Ministério da Saúde do Brasil. Os dados foram tabulados no software Epidata 3.1 e analisados no SPSS 21.0, resultando em uma amostra de 174 administrações e prescrições. Resultados: Os diagnósticos de internamento mais frequentes para uso do antimicrobiano foram doenças do aparelho respiratório (52,9\%) seguida de doenças do aparelho urinário (5,7\%). Os principais tipos de erros de prescrição foram ausência da informação sobre o diluente (97,1\%), velocidade de infusão (99,4\%), dose incorreta $(5,8 \%)$ e abreviaturas proibidas $(1,1 \%)$. Nas administrações observou-se os tipos de erros de falta de identificação do paciente pelo profissional $(94,3 \%)$, falta de identificação do paciente no leito $(12,1 \%)$, horário de administração $(6,3 \%)$ e técnica incorreta de preparo e administração do medicamento (1,1\%). Conclusão: Foram avaliados os principais fatores que levaram aos erros de prescrição e administração, se fazendo necessário melhorias no prontuário eletrônico com padronização para diluição dos antimicrobianos, emissão de alertas na prescrição, integração de um farmacêutico clínico na equipe, comunicação efetiva e treinamento e capacitação permanente.
\end{abstract}

Palavras-chave: erros de medicação, segurança do paciente, pediatria, prescrições de medicamentos, anti-infecciosos. 


\section{Introduction}

Since the discovery of antimicrobial agents (ATMs), the treatment of infectious diseases has taken new directions, where millions of lives have been saved worldwide. However, the resistance of the microorganisms to these drugs has increased steadily in the last decade, reaching levels of a global public health problem, which represents serious risks to human health. ${ }^{1}$ The increase in the use of antimicrobial therapy has become a global concern regarding its rational use and has generated important clinical and economic consequences for the health system and hospital institutions. ${ }^{2}$

In this scenario, another emerging global public health problem is medication errors (MEs), defined as any preventable event which, in fact or potentially, can lead to the inappropriate use of medications, ${ }^{3}$ which causes financial losses and harms to the health of patients and professionals alike, and which can be classified as prescription, dispensation and administration errors. ${ }^{4}$ A national study showed that $39 \%$ of the errors occur during prescription and $38 \%$, during administration. ${ }^{5}$ A study published in the United States of America (USA), showed that every hospitalized patient is susceptible to one ME a day. ${ }^{6}$ Thus, the occurrence of MEs involving ATMs can generate multi-resistant microorganisms with impacts on the available therapeutic arsenal, increased hospital costs, and higher morbidity and mortality in the patients. ${ }^{1-5}$

A study carried out in a teaching hospital to analyze such errors observed that the therapeutic class with the highest frequency of MEs notification was that of ATMs, corresponding to $19 \%$ of the records. This high rate has caused concern regarding the contribution of MEs to microbial resistance. ${ }^{7}$ In view of the reflexes of these errors on health, in 2004 the World Health Organization (WHO) launched the World Alliance for Patient Safety (PS) and, in 2013, Brazil created the National PS Program with objectives regarding health qualification and mitigation of adverse events; in 2017, the WHO published the third global PS challenge, with the theme of "Medication without harms", with the objective of reducing MEs by $50 \%$ in the next 5 years. ${ }^{8}$

It is important to highlight that the therapeutic class of the ATMs is the most prescribed in Pediatrics, with children using it twice as much as adults. Due to the specificities of their metabolism, such as age, weight, body surface area, absorption capacity, biotransformation, and drug excretion, children are more susceptible to harms. In addition, as clinical tests are rare in this population, there is no standardization for the prescription of medications in Pediatrics and the effects are observed after their use in the clinical practice. ${ }^{9,10} \mathrm{An}$ error in the dose of a medication can cause serious harms to health; therefore, the pediatric prescription requires dose adjustment based on weight, age and body surface area, with administration being performed with care and attention. ${ }^{11}$

It is noteworthy that MEs in Pediatrics is a major problem for health systems worldwide. A study carried out in 2011 in São Paulo, points to 1.15 occurrences of errors per 1,000 patients-days in the pediatric sector $^{10}$. Another study classified the main MEs in this age group, indicating that $77.8 \%$ correspond to errors in the prescription stage, followed by administration errors with $12.8 \%{ }^{12}$

In this perspective, given the high frequency of MEs in Pediatrics, as well as the indiscriminate use of ATMs, it is necessary to investigate the occurrence of these incidents in this age group and the associated factors. Therefore, this study aimed to identify errors in the prescription and administration of antimicrobials in a pediatric inpatient unit of a public teaching hospital.

\section{Methods}

A cross-sectional study with a quantitative approach carried out from April to July 2019 in a public teaching hospital in the Southwest region of Bahia. This hospital, classified as large, with medium- and high-complexity care, is linked to the Unified Health System (Sistema Único de Saúde, SUS) network through the State Health Secretariat of Bahia (Secretaria Estadual de Saúde da Bahia, Sesab); it has 276 beds and serves 27 municipalities in the South Regional Health Base, with a population of more than 600,000 inhabitants.

The analyzed sample came from the Pediatrics sector, where the administrations (understood as preparation and administration of the medication) of ATMs and their respective prescriptions (prescribed antimicrobial item) were observed. Sample calculation was performed with the aid of the Epi info 7.0 program, considering an alpha error of $5 \%$ and a beta error of $10 \%$, having as reference the work of Melo and Pedreira, ${ }^{13}$ performed in a pediatric unit of a university hospital $(1,717$ registration errors in 8,152 doses of drugs analyzed), requiring 174 observations of administrations and of their respective prescriptions.

The following inclusion criteria were defined: ATMs administrations performed by all the nursing technicians/assistants, in the daytime service, who have worked for more than two months in this sector and the prescription corresponding to each ATM item. As an exclusion criterion, administrations performed in the night service and nursing technicians who were on vacation or on leave during the data collection period.

For the ATM administration errors, failures during the preparation and administration of the medication were compared to the medical prescription, non-compliance with the recommendations or guidelines of the hospital or the technical instructions of the product manufacturer.

For the assessment of ATM preparation and administration, the direct observation technique was used, that is, at times standardized in the sector $(08,10,11,12,14,16,17$ or 18 hours depending on the frequency of administration) considering the day shift, the researcher monitored the preparation and administration of medications and took down detailed notes of what was done during the entire process. ${ }^{14}$ The nursing technicians responsible for the administration of medications in the daytime service were invited to participate in the study and signed the Free and Informed Consent Form (FICF), at a time prior to the beginning of the observations.

This stage was conducted by a properly trained researcher who observed and recorded the following data: dilution, time of administration, dose administered, dose omission, administration route, preparation technique, administration technique, patient who received the medication, and patient identification on the bed, in a form previously validated by a pilot test. ${ }^{16}$ This information was later checked with the prescription, the hospital guides or the manufacturer's instructions. After the observation of the administration, the prescriptions and the prescribed ATM item were analyzed, using a validated checklist form ${ }^{15}$ for the analysis of errors according to the Brazilian safety protocol in the prescription, use and administration of medications ${ }^{3}$.

The dependent variables were the types of ATM prescription and administration errors. The types of administration errors considered were the following: a) Dose administration error: when the dose administered was different from the one prescribed; 
b) Errors in the administration route: when the administration was carried out via a different route from the one prescribed; c) Time error: when the administration occurred 30 minutes before or after the prescribed time; d) Wrong patient: when the patient who received the medication was different from the one for whom the medication was prescribed; e) Unidentified patient: when there was no identification of the patient's name and date of birth, mother's name or medical record number on the bracelet or the bed; f) Preparation technique error: when it was different from that recommended by the hospital and/or manufacturer; g) Dose omission: when not checked and administered by the Nursing team. ${ }^{14}$

With regard to the prescription errors, the following items were considered: incompleteness, illegibility and absence of data such as name, age, weight of the patient, date of prescription, bed, prescription of the medication according to the Brazilian Common Denomination (Denominação Comum Brasileira, $D C B$ ), pharmaceutical form, administration route, frequency of administration, dose, in addition to the signature, specialty and stamp of the prescriber, duration of the treatment, use of nonstandard abbreviations, hospitalization unit, and medical record number. ${ }^{3}$ The doses were calculated according to the patient's weight and age; it was considered an error when the dose prescribed was below or above the recommended by the leaflet for the professional available in the Brazilian National Health Surveillance Agency (ANVISA) electronic lefalet database ${ }^{16}$ for the treatment of the disease.

The independent variables were the clinical and sociodemographic data (gender, age, inpatient diagnosis, and diagnosis of ATM use), which were collected from the patient's medical record; for this reason, parents or guardians were informed about the study, invited to participate and to sign the FICF. This assessment was carried out in that order for ethical reasons ${ }^{16}$, as the researcher could not observe a prescription error and communicate it to the team before administering the medication to the patient.

Regarding age, the patients were divided into age groups according to the definition by Ferreira et al. ${ }^{17}$ : infant (between 28 days old and $<2$ years old), pre-school (between 2 and $<6$ years old), school (between 6 and $<12$ years old), and adolescents (between 12 and $<19$ years old). The medications were classified according to the Anatomical Therapeutical Chemical (ATC) classification, third level (pharmacological subgroup) ${ }^{18}$. The inpatient diagnoses were classified according to ICD-11 (International Code of Diseases and Health-Related Problems), published by the WHO to identify and standardize diseases universally. ${ }^{19}$

For data tabulation, Epidata version 3.1, 2008, was used, and data analysis was performed in the IBM Statistical Package for the Social Sciences (SPSS), version 21.0, 2015 (IBM Corp, Armonk, United States of America).

The sociodemographic variables, the administration and prescription errors, were described as absolute and relative frequencies, while median and interquartile range were used for the continuous variables. Pearson's chi-square test was used to analyze statistical associations, with a significance level of $p<0.05$.

The study followed the ethical principles set forth in Resolution No. 466/1220 of the National Health Council (Conselho Nacional de Saúde, CNS), with approval by the Ethics and Research Committee of the State University of Sudoeste da Bahia, CAAE No. 29780014.8.0000.0055 and opinion No. 703,376.

\section{Results}

A total of 174 drug administrations and their respective prescriptions were analyzed, $69.5 \%$ of which corresponded to male patients and $30.5 \%$ to female patients, aged between 3 and 159 months old (median of 30.5 and interquartile range of 65), with higher frequency of the infant age group: $43.7 \%$.

As for the diagnoses identified, there is a higher frequency of diseases of the respiratory system in the infant, pre-school, and school age groups with $52.9 \%$ [other viral pneumonias (27.6\%), acute bronchiolitis due to other specified microorganisms $(10.9 \%)$, unspecified bronchopneumonia (5.2\%), unspecified acute bronchitis (4.0\%), acute upper airway infection (2.9\%), asthma (1.1\%), respiratory failure not classified elsewhere (0.6\%), cough $(0.6 \%)$ ], as shown in Table 1 . The diseases of the urinary system $(5.7 \%)$ included urinary tract infections (4.0\%), nephrotic syndrome (1.1\%) and proteinuria (0.6\%).

The study verified the use of 16 different ATMs, belonging to 13 ATC classes, with a predominance of broad spectrum penicillin (ampicillin and amoxicillin), $3^{\text {rd }}$ generation cephalosporin (ceftriaxone), and $\beta$-lactamase resistant penicillin among all the age groups, as shown in Table 1.

In the identification of the prescriptions (full name of the patient without abbreviations, medical record number, bed number, full name of the prescriber, registration number with the professional council, signature of the prescriber, full name of the institution, and identification of the prescription date) all the data were filled in correctly. There were also no errors regarding standardization in the DCB, medications with similar names, use of non-metric measurement expressions, pharmaceutical form with all the necessary information, unit of measurement clearly indicated, and use of zero before the decimal point. The predominant types of prescription errors referred to information on the diluent and infusion speed, the dose error being more associated with the school age group, as shown in Table 1. Regarding the therapeutic class, errors of forbidden abbreviation, abbreviated administration route, and dose were more frequent in $3^{\text {rd }}$ generation cephalosporin, as shown in Table 2.

Regarding the types of administration errors, the most frequent was absence of patient identification by the professional who administered the medication, as shown in Tables 1 and 2, with an association between the infant age group for the identification of these patients at the bedside and patient identification by the nursing technician/assistant. Errors regarding the preparation and administration technique were observed with two classes of ATMs: beta-lactamase resistant penicillins (oxacillin) and antibiotics (amphotericin B) $(p<0.001)$, as shown in Table 2.

\section{Discussion}

The findings of the present study show a high occurrence of ATM prescription and administration errors in the pediatric population analyzed. The main results related to prescription errors draw the attention to lack of information about the diluent (97.1\%) and about the infusion rate (99.4\%); regarding errors in administrations, emphasis is given to the professional not identifying the patient (94.3\%). These findings corroborate the worldwide concern about the notorious health problem associated with the context of increased bacterial resistance..$^{1,7}$ 
Table 1. Proportion between inpatient diagnosis, classification of the antimicrobials, according to the Anatomical Therapeutic Chemistry (ATC) classification, and types of prescription and administration errors with age group, in the Pediatric sector of a public hospital. Bahia, Brazil, 2019.

\begin{tabular}{|c|c|c|c|c|c|}
\hline \multirow[b]{2}{*}{ ICD-10 Diagnosis } & \multicolumn{4}{|c|}{ Age groups $n(\%)$} & \multirow[b]{2}{*}{$p$-value } \\
\hline & $\begin{array}{l}\text { Infant } \\
N=76\end{array}$ & $\begin{array}{l}\text { Pre-school } \\
\mathrm{N}=51\end{array}$ & $\begin{array}{l}\text { School } \\
N=42\end{array}$ & $\begin{array}{l}\text { Adolescent } \\
\mathrm{N}=5\end{array}$ & \\
\hline \multicolumn{6}{|l|}{ Clinical conditions $^{1}$} \\
\hline Respiratory tract diseases & $44(57.9)$ & $31(60.8)$ & $18(42.9)$ & - & \\
\hline Abscess & $12(15.8)$ & $10(19.6)$ & - & - & \\
\hline Urinary tract diseases & $2(2.6)$ & $5(9.8)$ & $2(4.8)$ & $1(20.0)$ & \\
\hline Mumps & $10(13.2)$ & $0(0.0)$ & - & - & \\
\hline Fracture & - & $2(3.9)$ & $4(9.5)$ & $1(20.0)$ & $<0.001$ \\
\hline Leishmaniasis & $6(7.9)$ & $1(2.0)$ & - & - & \\
\hline Arthritis & - & - & $4(9.5)$ & $3(60.0)$ & \\
\hline Meningitis & - & - & $7(16.7)$ & - & \\
\hline Others ${ }^{2}$ & $2(2.6)$ & $2(4.0)$ & $7(16.7)$ & - & \\
\hline \multicolumn{6}{|l|}{ Medications used, ATC } \\
\hline Broad spectrum penicillin & $36(47.4)$ & $16(31.4)$ & $9(21.4)$ & - & \\
\hline $3^{\text {rd }}$ generation cephalosporin & $10(13.2)$ & $17(33.3)$ & $18(42.9)$ & $1(20.0)$ & \\
\hline$\beta$-lactamase resistant penicillin & $15(19.7)$ & $9(17.6)$ & $8(19.0)$ & $2(40.0)$ & \\
\hline Combinations of penicillins, including $\beta$-lactamase inhibitors & $7(9.2)$ & $3(5.9)$ & $1(2.4)$ & - & \\
\hline $1^{\text {st }}$ generation cephalosporin & - & $5(9.8)$ & $1(2.4)$ & $1(20.0)$ & \\
\hline Other aminoglycosides & $3(3.9)$ & - & - & - & \\
\hline Nucleoside and nucleotide reverse transcriptase inhibitors & - & - & $3(7.1)$ & - & $<0.001$ \\
\hline Antibiotics & $2(2.6)$ & - & - & - & \\
\hline Lincosamides & $1(1.3)$ & $1(2.0)$ & - & - & \\
\hline Macrolides & $1(1.3)$ & - & $1(2.4)$ & - & \\
\hline$\beta$-lactamase sensitive penicillin & $1(1.3)$ & - & - & - & \\
\hline Fluorquinolones & $0(0)$ & - & - & $1(20.0)$ & \\
\hline Imidazole derivatives & $0(0)$ & - & $1(2.4)$ & - & \\
\hline Prescription Errors & $145(41.0)$ & 106 (29.9) & $92(26.0)$ & $11(3.1)$ & \\
\hline Forbidden abbreviations & $1(50.0)$ & - & $1(50.0)$ & - & 0.746 \\
\hline Abbreviated administration route & $2(50.0)$ & $1(25.0)$ & $1(25.0)$ & - & 0.980 \\
\hline Dose & - & $3(30.0)_{a, b}$ & $6(60.0)_{b}$ & $1(10.0)_{a}$ & $0.004^{3}$ \\
\hline Diluent & $71(42.0)$ & $51(30.2)$ & $42(24.9)$ & $5(3.0)$ & 0.084 \\
\hline Infusion speed & $71(43.4)$ & $51(29.5)$ & $42(24.3)$ & $5(2.9)$ & 0.730 \\
\hline Administration Errors & $97(48.7)$ & $59(29.6)$ & $38(19.1)$ & $5(2.6)$ & \\
\hline Dose & $1(100.0)$ & - & - & - & 0.730 \\
\hline Time of administration & $5(45.5)$ & $5(45.5)$ & $1(9.1)$ & - & 0.477 \\
\hline Preparation and administration technique & $2(100.0)$ & - & - & - & 0.456 \\
\hline Patient identified at bedside & $14(66.7)_{a}$ & $6(28.6)_{a, b}$ & - & $1(4.8)_{\mathrm{a}}$ & $0.030^{3}$ \\
\hline The technician identified the patient & $75(45.7)$ & $48(29.3)$ & $37(22.7)$ & $4(2.3)^{\circ}$ & 0.056 \\
\hline
\end{tabular}

In a study ${ }^{10}$ conducted in a Pediatric hospital in São Paulo-SP, a predominance of errors related to the infusion rate was also observed. Another study carried out in three pediatric units of a university hospital, observed registration errors in $21.1 \%$ of the medication doses, with errors of dose omission by nursing standing out, which corresponded to $75.7 \%$ of the failures. ${ }^{13}$ Although in the present study this error was observed with lower prevalence, it is worth emphasizing the importance of monitoring and correcting this practice, aiming at providing the necessary dose to the patient.

International studies corroborate the high risk of the occurrence of MEs in children. In Western Ethiopia, the researchers observed that in the pediatric wards of a Reference Hospital, $67.97 \%$ of the pediatric patients were exposed to at least one $\mathrm{ME}$, with errors in dosage and incorrect selection of medications being the most frequent prescription errors. ${ }^{21}$
A Danish study, ${ }^{22}$ based on a national mandatory notification system, evaluated MEs in pediatric inpatients and verified that most of them occurred during prescription, with dosage errors being more common, and with ATMs and analgesics being the most frequently reported classes of medications. In contrast, a study carried out in two university hospitals in the USA ${ }^{23}$ recorded that $28.6 \%$ of the patients had at least one ME during hospitalization. It should be noted that these differences can be related to the intrinsic characteristics of the populations studied, as well as in the definitions and methods used to detect errors, among other factors.

With regard to the diagnoses found, a survey conducted in Western Paraná, verified that $55.6 \%$ of the hospitalizations of children under five years old are due to respiratory problems, corroborating with the results found in this research. ${ }^{24}$ Risk factors 
Table 2. Proportion of types of prescription and administration errors with the classification of the antimicrobials, according to the Anatomical Therapeutic Chemistry (ATC) classification, in the Pediatric sector of a public hospital. Bahia, Brazil, 2019.

\begin{tabular}{|c|c|c|c|c|c|c|c|c|c|c|}
\hline \multirow[b]{2}{*}{ ATC ClasS } & \multicolumn{5}{|c|}{ Types of Prescription Errors n (\%) } & \multicolumn{5}{|c|}{ Types of Administration Errors $n$ (\%) } \\
\hline & $\begin{array}{l}\text { Forbidden } \\
\text { abbreviation }\end{array}$ & $\begin{array}{l}\text { Abbreviated } \\
\text { adm. }{ }^{1} \text { route }\end{array}$ & Dose & Diluent & $\begin{array}{l}\text { Infusion } \\
\text { speed }\end{array}$ & Dose & Team & $\mathrm{BP}^{2}$ & TDNIP $^{3}$ & $\begin{array}{l}\text { Preparation } \\
\text { and adm. }\end{array}$ \\
\hline Broad spectrum penicillin & - & - & - & $59(34.9)$ & $61(35.3)$ & - & $6(54.5)$ & $3(14.3)$ & $60(36.7)$ & - \\
\hline $\begin{array}{l}3^{\text {rd }} \text { generation } \\
\text { cephalosporin }\end{array}$ & $1(50.0)$ & $2(50.0)$ & $5(50.0)$ & $46(27.2)$ & $46(26.6)$ & - & $2(18.2)$ & $8(38.1)$ & $41(25.0)$ & - \\
\hline $\begin{array}{l}\beta \text {-lactamase resistant } \\
\text { penicillin }\end{array}$ & - & - & $1(10.0)$ & $34(20.1)$ & 34 (19.6) & $1(100.0)$ & $2(18.2)$ & $6(28.5)$ & $31(18.9)$ & $1(50.0)$ \\
\hline $\begin{array}{l}\text { Combinations of penicillins, } \\
\text { including } \beta \text {-lactamase } \\
\text { inhibitors }\end{array}$ & - & $1(25.0)$ & $1(10.0)$ & $11(6.5)$ & $11(6.3)$ & - & - & $2(9.5)$ & $11(6.7)$ & - \\
\hline $\begin{array}{l}1^{\text {st }} \text { generation } \\
\text { cephalosporin }\end{array}$ & - & - & - & $7(4.1)$ & $7(4.0)$ & - & $1(9.1)$ & - & $7(4.3)$ & - \\
\hline Other aminoglycosides & - & - & - & $3(1.8)$ & $3(1.7)$ & - & - & - & $3(1.8)$ & - \\
\hline $\begin{array}{l}\text { Nucleoside and nucleotide } \\
\text { reverse transcriptase } \\
\text { inhibitors }\end{array}$ & - & - & $3(30.0)$ & $3(1.8)$ & $3(1.7)$ & - & - & - & $3(1.8)$ & - \\
\hline Antibiotics & - & - & - & $1(0.6)$ & $1(0.6)$ & - & - & - & $2(1.2)$ & $1(50.0)$ \\
\hline Lincosamides & - & - & - & $1(0.6)$ & $2(1.2)$ & - & - & $1(4.8)$ & $2(1.2)$ & - \\
\hline Macrolides & $1(50.0)$ & $1(25.0)$ & - & $2(1.2)$ & $2(1.2)$ & - & - & $1(4.8)$ & $2(1.2)$ & - \\
\hline $\begin{array}{l}\beta \text {-lactamase sensitive } \\
\text { penicillin }\end{array}$ & - & - & - & - & $1(0.6)$ & - & - & - & $1(0.6)$ & - \\
\hline Fluorquinolones & - & - & - & $1(0.6)$ & $1(0.6)$ & - & - & - & - & - \\
\hline Imidazole derivatives & - & - & - & $1(0.6)$ & $1(0.6)$ & - & - & - & $1(0.6)$ & - \\
\hline$p$-value ${ }^{4}$ & $<0.001$ & 0.010 & $<0.001$ & $<0.001$ & $<0.001$ & 0.981 & 0.982 & 0.338 & 0.027 & $<0.001$ \\
\hline
\end{tabular}

that can contribute to these hospitalizations are exposure to environmental pollutants, such as smoking, overcrowding in the home, interruption of breastfeeding, insertion of a child with an immune system still developing in environments such as daycare centers and schools, and climatic seasonality, among others. ${ }^{25}$ According to Ceyhan et al., ${ }^{26}$ these factors most frequently affect children under five years old, in the infant and pre-school phase.

The hospitalization rate was higher in male than in female children, which can be associated with the immune response to vaccination against agents that cause respiratory disorders, such as influenza, as well as with the response to antiviral therapies, in addition to behavioral factors, where boys tend to be more active than girls, with a higher risk of exposure to environmental pathogens, among other factors. ${ }^{27}$

Broad-spectrum penicillins were the most commonly used ATM class in Pediatrics, followed by $3^{\text {rd }}$ generation cephalosporin and by beta-lactamase resistant penicillins. These data corroborate the study by Ceyhan et al., ${ }^{26}$ where there was a higher prevalence of these classes in a Pediatric hospital. This use is justified by the fact that these ATMs are the most indicated for the treatment of respiratory diseases, ${ }^{28}$ which are most observed in this study, since according to the literature they have good safety and effectiveness in children. ${ }^{9}$

With regard to systemic factors to mitigate errors, electronic prescriptions (EPs), from computerized systems stand out, as they considerably increase safety when prescribing and administering medications. ${ }^{29}$ In this study, it was possible to observe the importance of EPs, regarding the identification of the prescription, as there were no errors in this information. There are still advantages such as easy and quick access to the patient's history, clear organization of information, improvement in therapeutic planning, and simultaneous sharing with the multidisciplinary team. ${ }^{30,31}$
In addition to this, other strategies can be incorporated into the routine in order to minimize these errors and improve the flow of the medication, such as improving the effective communication between the professionals involved, carrying out medication reconciliation, incorporating the clinical pharmacist in the team, preparing explanatory handbooks that can subsidize the training and qualification of health workers, addition of automatic alerts in EPs, and implementation of unit dose and barcode in the administration of medications. ${ }^{32}$ Added to this is the importance of encouraging notifications of adverse events and analysis of the root cause of the errors, among other strategies, as long as they are consistent with the structure and profile of occurrences serviced by the hospital. ${ }^{32,33}$

Some prescriptions had forbidden abbreviations and abbreviated administration route outside the standard. The Brazilian protocol for safety in the prescription, use and administration of medications ${ }^{3}$ suggests that some abbreviations are not to be used so as not to confuse the professional during administration, in order to minimize possible MEs and harms to the patient. If these abbreviations are indispensable, the ANVISA recommends standardizing them within the hospital, availing a list for access by all the professionals. ${ }^{34}$

Dose-related errors were restricted to certain classes of medications, such as beta-lactamase resistant penicillins, and associated with the school age group (between 6 and $<12$ years old). An underdose will not have the desired effect and can cause the bacteria to resist the drug, while an overdose can cause intoxication and other harms to the patient. A number of studies carried out with children found inadequacies such as overdose with $14.6 \% 9$ and $53.9 \% .{ }^{35}$ Gonçalves et al. ${ }^{36}$ analyzed the use of systemic ATMs in children and adolescents and verified that the younger the pediatric age group, the greater the inadequacy of the medication, requiring an adequate dose. 
Thus, development of microbial resistance occurs when, in the presence of ATMs, the microorganisms are able to adapt and grow, resisting the action of the medication, and thus decreasing or eliminating its effectiveness. ${ }^{37}$ This resistance has been a global public health concern, due to the inappropriate use of ATMs, which implies problems with ineffective treatments, longer hospital stays, and increased mortality and costs for the health services. ${ }^{38}$ In this sense, the Institute for Safe Practices in the Use of Medications (Instituto para Práticas Seguras no Uso de Medicamentos, ISMP, Brazil) reinforces the need to check doses before prescribing, dispensing, preparing or administering drugs, especially in the context of the use of systemic ATMs. ${ }^{39}$

Regarding the prescriptions, a fact that draws the attention in this study is noticing that this information about diluent and infusion speed is absent in practically all of them. It should be noted that this information is an important indication so that there are no doubts or causes errors in the administration by the nursing professional, as reported in some studies. In a study conducted in a Sentinela hospital in Rio Branco-AC, ${ }^{40} 29.9 \%$ of the prescriptions did not include the type and volume of the diluent for the preparation of the drugs, which is a contributing factor to errors that result in difficulty dissolving injectable pharmaceutical forms, in addition to provoking inactivation or precipitation of the active supply, as highlighted by the author

The lack of information about the infusion speed or conducting the technique at an inappropriate speed can compromise the safety of the administration process. In the research by Yamamoto et al., ${ }^{10}$ the error related to the wrong infusion rate predominated. In an observation made in five hospitals in the United Kingdom, among the most common MEs, errors in medication administration with incorrect infusion rate stood out. ${ }^{41}$

It is worth noting that these problems can be solved with the presence of a clinical pharmacist in integration with the multiprofessional team and with the parameterization of data such as diluent and infusion speed to be included in the electronic prescription. ${ }^{42}$ In addition, another effective solution would be adopting the use of the dilution handbook, which, adapted to the local reality, was prepared in the hospital as a resource to be used when necessary. This handbook was a contribution from undergraduate Pharmacy students and its development was based on the Micromedex Drug Interaction ${ }^{43}$ program and on the package insert for reference drugs, available on the ANVISA electronic form. ${ }^{16} \mathrm{~A}$ number of studies point out that the elaboration of handbooks for standardizing techniques that aim at the safe use of medications has proved to be a valuable tool for guiding the professionals from the point of view of health care, both in teaching and research activities. ${ }^{44,45}$

As for the medication administration process, an important point to be observed in the routine is related to the existence of a common practice in hospitals, which is the standardization of administration times, which can contribute to a potential drug interaction. ${ }^{46}$ Some errors were found regarding the schedule, due to the accumulation of medications to be administered simultaneously and to an insufficient number of professionals to perform the administration, in addition to the fact that children have a difficult venous access, causing vein loss and delays in these times. Other studies relate the scheduling practice to the occurrence of drug interactions and MEs, which draws the attention to a more accurate survaillance regarding the medication administration times. . $^{47,48}$
Among the safety requirements, another fact that should be highlighted is the identification of patients, both on the bed or on the bracelet and by the professional during administration. At the local study hospital, it was observed that $12.1 \%$ of the patients were unidentified, associated with the infant age group, and that $94.3 \%$ of the nursing technicians/assistants did not perform patient identification at the time of administration. This approach suggests an increase in the possibility of MEs related to these patients. In their study, Hoffmeister and Moura ${ }^{49}$ evidenced the importance of using an identification bracelet, being the safest method to avoid failures during medication administration.

It is worth highlighting the need for a strict observation and incorporation of the items established as goals, instituted by the National PS Program for the monitoring and prevention of harms in health care, ${ }^{50}$ with the purpose of implementing the safety culture as a routine in the hospital environment that provides care for pediatric patients.

In view of the discussions raised in this study, it can be pointed out as a limitation the fact that the questionnaire applied was restricted only to prescription and administration errors and not observing clinical data such as laboratory tests to justify the use of ATMs. We can also list the impossibility of establishing causality among the data found, due to the study design and the failure to measure the clinical outcomes associated with the errors found. For purposes of comparison with other studies and generalization of the data, it is highlighted that the study was carried out in only one hospital, suggesting the need to expand this investigation to obtain more solid results.

However, the study contributes to the discussion of data related to MEs in Pediatrics involving ATMs, problems that have generated worldwide concern regarding PS and the increase in the rate of bacterial resistance. Notwithstanding this, these data reinforce the need for the inclusion of the clinical pharmacist to assist in the pharmacotherapeutic follow-up of the pediatric population, in order to optimize the use of medications in a safer and more effective way by these age groups, in addition to assisting the team in minimizing errors in the administration and prescription of antimicrobials.

\section{Conclusion}

It was possible to verify that the errors during dose prescription were associated with the school age group and that the identification errors on the bed or on the bracelet were associated with the infant age group. Thus, actions that promote the rational use of ATMs are necessary to reduce errors and the advancement of microbial resistance.

The need to implement a patient identification protocol and a continuing education program for the professionals is also emphasized, in addition to parameterizing the dilution of medications, with information such as diluents and infusion speed, with the inclusion of these data in the electronic prescription or the use of the dilution handbook present in the hospital and inclusion of a clinical pharmacist in the multiprofessional team.

\section{Funding sources}

None. 


\section{Collaborators}

GMM and GSL: Design of the project or data analysis and interpretation and editing of articles or critical review relevant to the intellectual content. TSS and LBL: Writing of the article or critical review relevant to the intellectual content.

\section{Conflict of interests statement}

The authors declare that there are no conflicts of interest in relation to this article.

\section{References}

1. Pan American Health Organization. Florida International University. Recommendations for Implementing Antimicrobial Stewardship Programs. In: Latin America and the Caribbean: Manual for Public Health Decision-Makers. Washington, D.C. PAHO, FIU; 2018.

2. Loureiro RJ, Roque F, Rodrigues AT, et al. O uso de antibióticos e as resistências bacterianas: breves notas sobre a sua evolução. Ver. Port. Sau. Pub. 2016; 34(1): 77- 87.

3. Brasil. Ministério da Saúde. Agencia Nacional de Vigilância Sanitária. Protocolo de segurança na prescrição, uso e administração de medicamentos do programa nacional de segurança do paciente. 2013

4. Mota IVR, Almeida PHRR, Lemos LB, et al. Prescription errors and administration of injectable antimicrobials in a public hospital. Rev Bras Farm Hosp Serv Saude. 2018; 9(4): 1-6.

5. Marques TC, Reis AMM, Silva AEBC, et al. Erros de administração de antimicrobianos identificados em estudo multicêntrico brasileiro. Rev. Bras. Cienc. Farm. 2008; 44(2): 305-314.

6. Aspden P, Wolcott J, Bootman JL, et al. Committee on identifying and preventing medication errors. preventing medication errors. institute of medicine of the national academies. Washington, Institute of Medicine National Academy Press, Washington DC. 2007; 544.

7. D’ Aquino FFR, Flávia FR, Carmen $\mathrm{MCl}$, et al. Incidentes relacionados a medicamentos em uma instituição hospitalar: subsídios para a melhoria da gestão. Rev Enferm UERJ. 2015; 23(5): 616-21.

8. Organização Mundial de Saúde. OMS. Medication without harm: WHO's third global patient safety challenge. Geneva: WHO, 2017.

9. Inumaru FE, Silva AS, Soares AS,et al. Perfil e adequação do uso de antibacterianos em crianças internadas em hospital geral no sul do Brasil. Revista Paulista de Pediatria. 2019; 37(1): 27-33.

10. Yamamoto MS, Peterlini MAS, Bohomol E. Notificação espontânea de erros de medicação em hospital universitário pediátrico. Acta Paul Enferm. 2011; 24(6): 766-771.

11. Proqualis. Erros de medicação: série técnica sobre Atenção Primária mais segura, 2018. 25p.

12. Fortescue EB, Kaushal R, Landrigan CP, et al. Prioritizing Strategies for Preventing Medication Errors and Adverse Drug
Events in Pediatric Inpatients. Pediatrics. 2003; 111(4): 722729

13. Melo LR, Pedreira MLG. Erros de medicação em pediatria: análise da documentação de enfermagem no prontuário do paciente. Revista Brasileira de Enfermagem. 2005; 58(2): 180-5.

14. Silva JSD, Almeida PHRF, Perini E, et al. Erros de prescrição e administração envolvendo um medicamento potencialmente perigoso. Rev Enferm UFPE on line. 2017; 11(10): 3707-3717.

15. Pires $A O M$, Ferreira MBG, Nascimento KG, et al. Elaboration and validation of the medication prescription safety checklist. Rev Latino Am Enfermagem 2017;25:e2921.

16. Brasil. Agência Nacional de Vigilância Sanitária. Bulário Eletrônico. Available at: http://www.anvisa.gov.br/datavisa/fila bula/index.asp. Accessed on: 05 oct. 2019.

17. Ferreira SB, Silveira CXCJ, Machado RLT, et al. Adequação às faixas etárias pediátricas de medicamentos novos registrados no Brasil de 2003 a 2013. Einstein. 2018; 16(4):1-8.

18. World Health Organization. Collaborating Centre for Drug Statistics Methodology. The ATC classification - structure and principles, 2018. 77/5000 Available at: <http://www.whocc. no/atc_ddd_index/>. Accessed on: 05 oct. 2019.

19. World Health Organization. CID-11: classificação estatística internacional de doenças e problemas relacionados à saúde. Available at: https://www.who.int/classifications/icd/en/. Accessed on: 02 oct. 2019

20. Brasil. Resolução no 466, de 12 de dezembro de 2012. Aprova diretrizes e normas regulamentadoras de pesquisas envolvendo seres humanos. Diário Oficial da União. 13 jun. 2013.

21. Fekadu G, Abdisa E, Fanta K. Erros de prescrição de medicamentos entre pacientes pediátricos hospitalizados no Hospital de Referência de Nekemte, oeste da Etiópia: estudo transversal. BMC Res Notes. 2019; 12 (1): 421.

22. Rishoej RM, Almarsdóttir AB, Christesen HT, et al. Erros de medicação em pacientes pediátricos internados: um estudo baseado em um sistema nacional de notificação obrigatória. Eur J Pediatr. 2017; 176: 1697-1705

23. Kaushal R, Bates DW, Landrigan C, et al. Erros de medicação e eventos adversos a medicamentos em pacientes pediátricos internados. JAMA. 2001; 285: 2114-2120.

24. Prezotto $\mathrm{KH}$, Lentsck MH, Aidar T, et al. Hospitalizations of children for preventable conditions in the state of Parana: causes and trends. Acta Paul Enferm. 2017; 30(3): 254

25. Trenholme A, Vogel A, Lennon D, et al. Household characteristics of children under 2 years admitted with lower respiratory tract infection in Counties Manukau, South Auckland. N Z Med J. 2012; 125(1367):15-23.

26. Ceyhan M, Yildirim I, Ecevit C, et al. Inappropriate antimicrobial use in Turkish pediatric hospitals: a multicenter point prevalence survey. Int J Infectious Dis. 2010; 14(1): 55-61.

27. Wang $\mathrm{X}$, Yang $\mathrm{L}, \mathrm{Chan} \mathrm{KH}$, et al. Age and sex differences in rates of influenza-associated hospitalizations in Hong Kong. Am J Epidemiol. 2015; 18:335-44.

28. Rodrigues FA, Bertoldi AD. Perfil da utilização de antimicro- 
bianos em um hospital privado. Ciênc. Saúde Colet. 2010; 15: 1239-1247.

29. Oliveira MAS, Lima AR. Análise das Prescrições Médicas Atendidas na Farmácia Central de um Hospital e Maternidade da Cidade de Tianguá, Ceará. Rev Cient da Facul de Educação e Meio Amb. 2015; 17(1): 228-248.

30. Crippa V, Dias RC. Vantagens da implantação do prontuário eletrônico na segurança do paciente e na otimização do trabalho do farmacêutico hospitalar. Infarma-Ciências Farmacêuticas. 2017; 29(3): 199-207.

31. Canêo PK, Rondina JM. Prontuário Eletrônico do Paciente: conhecendo as experiências de sua implantação. J. Health Inform. 2014; 6(2): 67-71.

32. Mieiro DB, Oliveira ÉBC, Fonseca REP, et al. Estratégias para minimizar erros de medicação em unidades de emergência: revisão integrativa. Rev. Bras. Enferm. 2019; 72 (Suppl 1): 307-314.

33. Ferracini FT, Marra AR, Schvartsman C, et al. Using positive deviance to reduce medication errors in a tertiary care hospital. BMC Pharmacol Toxicol. 2016;17(1):36.

34. Instituto para Prática Segura de Medicamentos. Erros de medicação associados a abreviaturas, siglas e símbolos. 2015 June; 4(2):1-7.

35. Oliveira AC, Paula AO. Discontinuation of antimicrobials and costs of treating patients with infection. Acta Paul Enferm. $2012 ; 25: 68-74$

36. Gonçalves AC, Caixeta CM, Reis AM. Analysis of the use of systemic antimicrobial drugs in children and teenagers in two teaching hospital. Rev Ciênc Farm Basica Apl. 2009;30: 177-82.

37. WHO World Health Organization. Global Action Plan on Antimicrobial Resistance. Geneva, 2015

38. ANVISA. Agência Nacional de Vigilância Sanitária. GVIMS, Gerência de Vigilância e Monitoramento em Serviços de Saúde. GGTES, Gerência Geral de Tecnologia em Serviços de Saúde. Diretriz Nacional para Elaboração de Programa de Gerenciamento do Uso de Antimicrobianos em Serviços de Saúde. Brasília, 2017. 90p.

39. Instituto para Práticas Seguras no Uso de Medicamentos (ISMP - Brasil). Antimicrobianos: erros de medicação, riscos e práticas seguras na sua utilização. 2019; 8(7): 1-14.

40. Opitz SP, Cassiani SHB. Sistema de medicação: análise dos erros nos processos de preparo e administração de medicamentos em um hospital de ensino [Tese]. Ribeirão Preto (SP): Escola de Enfermagem de Ribeirão Preto, Universidade de São Paulo; 2006. Doutorado em Enfermagem.

41. Ross LM, Wallace J, Paton JY. Medication errors in a paediatric teaching hospital in the UK: five years operational experience. Arch Dis Child. 2000;83:492-7.

42. Magalhães ACAF, Cantanhede AMFC, Drummond BM, et al. Avaliação da implantação do serviço de farmácia clínica na Unidade de Terapia Intensiva para contribuir na segurança do paciente. Rev Med Minas Gerais. 2016; 26 (5): 16-22.

43. Micromedex. Drug Interactions. Disponível em: https://www. micromedexsolutions.com/micromedex2/4.14.0/WebHelp/
Tools/Interactions/Drug_Interactions.htm. Acessado em 23 jul. 2019.

44. Marini DC, Pinheiro JT, Rocha CS. Avaliação dos erros de diluição de medicamentos de administração intravenosa em ambiente hospitalar para o desenvolvimento de um guia de diluição e administração dos mesmos. Infarma- Ciências Farmacêuticas. 2016; 28(2):81-89.

45. Bertolo MB, Ferreira BSA, Marchiore AG, et al. Construction of a manual of work processes and techniques from Centro de Dispensação de Medicamentos de Alto Custo (CEDMAC), Hospital de Clínicas, Unicamp. Rev Bras Reumatol. 2014; 54 (3): 185-191.

46. Galiza DDF, Moura OF, Barros VL, et al. Preparo e Administração de Medicamentos: erros cometidos pela equipe de enfermagem. Rev Bras Farm Hosp Serv Saúde. 2014; 5(2): 45-50.

47. Pires MAM, Santos PM. Erros de medicação em um hospital municipal do interior da Bahia. Uma análise do processo de prescrição e aprazamento. J Assist Farmac Farmacoecon. 2016:1 (3): 31-37.

48. Pereira FGF, Melo GAA, Galindo Neto NM, et al. Interações medicamentosas induzidas pelo aprazamento e os erros no preparo de antibacterianos. Rev Rene. 2018;19:e3322.

49. Hoffmeister LV, Moura GMSS. Uso de pulseiras de identificação em pacientes internados em um hospital universitário. Rev. Latino-Am. Enfermagem. 2015; 23(1): 36-43.

50. Brasil. Ministério da Saúde. Portaria no 529, de 1 de Abril de 2013- Institui o Programa Nacional de Segurança do Paciente (PNSP). 2013. 